\title{
STRATEGI PEMBENTUKAN KARAKTER INKLUSIF-PLURALIS MELALUI KETELADANAN MULTIKULTURAL KIAI DI PESANTREN NGALAH PASURUAN
}

\author{
Oleh: Achmad Yusuf \\ Universitas Yudharta Pasuruan
}

Email : achysf@yudharta.ac.id

\begin{abstract}
Abstrak
Tujuan penelitian ini mengungkapkan dan menganalisa (1) Nilai karakter inklusif-pluralis Santri Pesantren Ngalah, (2) Pembentukan karakter inklusif-pluralis santri Pesantren Ngalah. Penelitian ini menggunakan kualitatif dengan jenis studi kasus. Kehadiran peneliti bersifat mutlak, (human instrument). Jenis data (1) primer, dan (2) skunder. Penentuan informan (1) purposive sampling. (2) snowball sampling. Pengumpulan data 1) wawancara mendalam; 2) observasi partisipan; dan 3) dokumentasi. Teknik analisis data 1) reduksi data, 2) penyajian data, dan 3) penarikan kesimpulan/verifikasi. Pengecekan keabsahan data menggunakan kredibilitas, meliputi; (1) perpanjangan pengamatan, (2) triangulas (a) triangulasi sumber, (b) triangulasi teknik, dan (c) triangulasi waktu. Simpulan penelitian ini (1) karakter inklusif-pluralis santri di Pesantren Ngalah; karakter yang dapat menerima, mengakui, menghormati, dan menyakini adanya perbedaan, serta adanya keragaman ras, suku, bahasa, dan agama yang dapat hidup berdampingan di dalam suatu entitas yang pluralistik. (2) strategi pembentukan karakter inklusif-pluralis santri di pesantren Ngalah meliputi; (a) keteladanan multikultural kiai; pertama, multikultural kognitif, kedua, multikultural afektif, ketiga, multikultural psikomotorik. (b) mendiskusikan dawuh kiai dan Jawabul Masail; (c) pembelajaran berdasarkan pengalaman langsung, (d) keterlibatan santri dalam penyusunan karya Ngalah.
\end{abstract}

Kata kunci: karakter inklusif, multicultural, nilai

\section{Abstract}

Aim research this express and analyze (1) the inclusive character value of the santri Pesantren Ngalah, (2) formation of inclusive character-plu ralis santri Pesantren Ngalah. This study uses qualitativewith type of study the case. The presence of researchers is absolute, (human instrument). Type d ata (1) primary, and (2) secondary . determination of informants (1) purposive sampling, (2) snowball sampling. collecting data 1) in-depth interviews; 2) participant observation; and 3) documentation Data analysis techniques l) data reduction, 2) data presentation, and 3) conclusion 
drawing/verification. checking the validity of the data using credibility, covering; (1) extension of observation (2) triangulas (a) source triangulation, (b)technical triangulation, and (c)time triangulation. conclusion research this (1) the inclusive character of plu ralis santri in pesantren Ngalah; character who can accept, acknowledge, respect, and believe in differences, as well as their diversity race, ethnicity, language, and religion that can coexist in apluralistic entity . (2) Strategy for establishing santri's inclusive-pluralist character in Ngalah Islamic boarding school includes; (a) exemplary multicultural kiai; first, multicultural cognitive, second, multicultural affective, third, multicultural psychomotor. (b) discussing dawuh kiai and Jawabul Masail; (c) learning based on direct experience, $(d)$ santri involvement in preparation of Ngalah complaints work

Keywords: inclusive character, multicultural, value

\section{PENDAHULUAN}

Indonesia terdiri dari keragaman suku, budaya, agama dan bahasa. Keragaman ini di satu sisi menjadi sebuah perekat dan penguat masyarakat, namun disisi lain pemicu terjadinya konflik horizontal. Akhir-akhir ini agama dijadikana sebagai alat untuk kepentingan politik melalui radikalisme agama. Pesantren sebagai salah satu lembaga pendidikan Islam yang akhirakhir ini gencar memperoleh sorotan tajam karena dikaitkan dengan radikalisme maupun terorisme dan dianggap sebagai lahan subur untuk menyemaikan bibit-bibit kekerasan, penyebar radikalisme agama dan sesuatu yang sangat kontradiktif dengan rasa damai.

Terjadinya bom Bali I, pada 12 Oktober 2012 merupakan peristiwa awal yang menjadikan dasar bagi masyarakat umum bahwa pesantren merupakan sarang teroris yang mengesahkan dan mendidik santri (seolah menjustifikasi) untuk melakukan aksi kekerasan dengan mengatasnamakan ajaran agama. Penghuni pesantren mendapat label ekslusif, jumud ${ }^{1}, \mathrm{kaku}$ dan tidak memiliki sikap toleran, berdasarkan peristiwa tersebut dalam kancah nasional dan internasional banyak yang menyoroti adanya keterkaitan pesantren dengan gerakan radikalisme dan terorisme. Peristiwa ini didasarkan pada fakta empiris bahwa semua pelaku teror bom tersebut adalah orang-orang dari pesantren. Tiga pelaku terror bom seperti Mukhlas, Amrozi, dan Ali Imron mereka termasuk keluarga Pesantren al-Islam Lamongan Jawa Timur, selain itu mereka termasuk alumni Pesantren al Mukmin Ngruki Solo. Pelakupelaku yang lain ternyata ada hubunganya,

\footnotetext{
${ }^{1}$ Zakiyudin Baidhawy, Pendidikan Agama Berwawasan Multikultural (Jakarta: Erlangga, 2005), 135 
baik secara langsung maupun tidak langsung, dengan Pesantren al-Mukmin Ngruki yang di pimpin Abu Bakar Ba'asyir. Sebuah kewajaran jika tudingan anti toleran, radikalisme dialamatkan ke pesantren ini. Dalam kancah international Islamphobia merebak, implikasi dari tudingan tersebut menyebabkan pesantren sekaligus alumninya pun terstigmakan.

Tentu saja stigma tersebut ditolak oleh mayoritas pondok pesantren di Indonesia, terutama pesantren yang berideologi aswaja. Sebagai upaya untuk mengkonter stigma yang dialamatkan ke Pesantren Indonesia sebagai sarang teroris tersebut, maka dalam berbagai forum dan media, mengkampanyekan bahwa mainstream pondok pesantren di Indonesia adalah memiliki wawasan moderat dan anti-radikalisme. Pesantren yang memiliki faham dan mengajarkan radikal, eksklusif, dan terorisme seperti Ngruki dan jaringannya, hanyalah segelintir "pesantren" di antara kurang lebih dari 17.000 pondok pesantren yang ada di Indonesia. ${ }^{2}$ Fakta empiris dan historis bahwa Pesantren di Indonesia sebagai lembaga pendidikan Islam dan dakwah, memiliki tipologi dan distingsi yang berbeda, karena berpijak pada misi utamanya yaitu menyebarkan ajaran Islam dan mengembangkan tata kehidupan masyarakat sekitarnya dengan cara membangun tradisi kehidupan yang damai, aman dan mandiri. Selanjutnya dalam perkembangannya, pesantren dengan segenap sistem pendidikannya secara istiqamah tetap mempertahankan tradisi kedamaian, keseimbangan, dan keharmonisan lingkungan. Pondok pesantren secara doktriner tetap mengembangkan prinsip ukhuwah Islamiyah, ukhuwah wathaniyah, dan ukhuwah basyariyah dalam upaya memperkuat bangunan Negara

Kesatuan Republik Indonesia (NKRI) sekaligus ikut serta membangun tata kehidupan global yang damai. ${ }^{3}$

Karakteristik Islam yang ditampilkan oleh para ulama pemangku pesantren sebagaimana Nabi SAW mengajarkannya adalah penanaman dan pengembangan nilai-nilai infitah (inklusif), tawassut (moderat), musawah (persamaan), dan tawazun ( seimbang). Karena itu maka pesantren tampil pula sebagai agen pembudayaan nilai, norma, sekaligus pesan-pesan keagamaan yang memiliki nilai harmoni, kerukunan, persatuan, dan kedamaian bahkan para ahli menilai pesantren mempunyai peran yang

${ }^{2}$ Yusuf Hanafi, Model Pendidikan Pesantren Yang Toleran Dan Inklusif Berbasis Culture Of Peace Education Sebagai Upaya Mengikis Radikalisme Atas Nama Agama dalam Jurnal LP3-UM. 2016.

A. Sholihuddin, Pesantren dan Budaya Damai,dalam http://www.gpansor.org/?p=13308, diakses pada tanggal 07 Januri 2017. 
cukup signifikan dalam melestarikan budaya lokal, termasuk memelihara nilai-nilai dan tatanan sosial yang harmonis di sekelilingnya. ${ }^{4}$

Berpijak pada pemikiran tersebut di atas, dengan mengacu pada tujuan didirikannya pesantren, maka tanggung jawab pondok pesantren besar dan berperan strategis dalam mengimplementasikan pendidikan Islam yang rahmatan lil aalamin dengan menghormati dan menjunjung tinggi nilai-nilai kemanusiaan, kederajatan, humanis keberagaman yang inklusif dan moderat.

Pondok Pesantren Ngalah merupakan lembaga sosial keagamaan yang bergerak di bidang pendidikan dan social yang berada di bawah naungan Yayasan Darut Taqwa 02 Sengonagung berdiri sejak tahun 1985, Pesantren Ngalah ini didirikan oleh Kiai M. Sholeh Bahruddin yang berasal dari Gempol Pasuruan. Dalam perkembangannya, ponpes Ngalah Ngalah memberikan kontribusi wawasan tentang bagaimana hidup bermasyarakat saling menghargai, menghormati, dan menerima perbedaan, hal ini dibuktikan dengan terbitnya beberapa karya santri madrasah diniyah sebagai pedoman dalam hidup berbangsa dan bernegara. Seperti (1) menerjemah dan mengkaji piagam madinah, sebagai bentuk pemahaman karakter, sikap, dan tingkah laku dan akhlaq Nabi Muhammad terhadap masyarakat arab pada zamannya yang memiliki kebudayaan, adat, dan agama yang berbeda. (2) mengkaji Pancasila dan memberikan dasar ayat al-Qur'annya sebagai langkah dalam memberikan wawasan kepada santri bahwa pancasila tidak terlepas dari agama, karena nilai-nilai agama secara universal tercermin dalam pancasila. (3) Penyusunan kitab Fiqih Galak Gampil jilid 1,2,3,4, dan 5 yang di dalamnya memuat beberapa alternatif solusi dari beberapa permasalahan dalam kehidupan social (hablum minannas) dan masalah ubudiyah (hablum minallah) dari perspektif mazhab empat, (4) menyusun kitab fiqih jawabul masail bermadzhab empat jilid I dan II (2012), buku ensiklopedi fiqih yang merupakan cerminan sajian hukum fikih berdasarkan pada pendekatan sosio-kultural dengan judul Jawabul Masail bermadzhab empat (2013). (5) menerbitkan khutbah dengan judul koleksi khutbah ala pesantren ngalah cerminan nilai kedamaian edisi I, II, dan III (2007-2011). Isi khutbah tersebut memuat tema yang mencerminkan nilai-nilai kedamaian, toleransi, tolong menolong, saling mengenal dan saling

4 Nunu Ahmad an-Nahidil, "Pesantren dan Dinamika Pesan Damai" dalam Edukasi, Jurnal Penelitian Agama dan Keagamaan, Vol.4 No.3 (Jakarta: Puslitbang Pendidikan Agama dan Keagamaan, Badan Litbang dan

Diklat Departemen Agama RI, 2006), 18 


\section{PENDIDIKAN MULTIKULTURAL}

berdampingan dalam bermasyarakat. Misalnya indahnya keragaman, Islam agama damai, Rukun dan Damai dalam perbedaan. ${ }^{5}$

Karya-karya di atas tidak hanya sekedar dalam tataran teoritis saja, akan tetapi telah dipraktikkan di Ponpes Ngalah. Misalnya kegiatan yang telah dilaksanakan adalah (1) seminar lintas agama dengan pembicara $\mathrm{KH}$. Abdurrahman Wakhid (Gus Dur) sebagai perwakilan dari agama islam pada tahun 2003, (2) Kolokium Alim Ulama Se-Indonesia dalam acara Peresmian Universitas Yudharta Pasuruan pada tahun 2004 yang di hadiri oleh semua tokoh lintas agama, (3) seminar nasional kerukunan antar umat beragama yang dihadiri oleh tokoh lintas agama serta mengundang dari vatikan (Roma) pada tahun 2006, (4) Seminar Kebangsaan dan Gebyar Budaya Umat beragama pada tahun 2010 yang menjadi nara sumber adalah tokoh lintas agama dan menghadirkan Rev Jasper Slop (Belanda), (5) live in 100 pendeta tahun 2010 selama 3 hari tinggal di Pesantren hidup bersama santri kegiatan ini sebagai tindak lanjut forum komunikasi antar umat beragama, (6) menerima kunjungan pendeta perwakilan yang berasal dari berbagai negara, mulai dari Filiphina, Srilanka, Papua, Jerman dan Indonesia (Medan, Nias) tahun 2011, (7) dialog "agama dan budaya" tingkat internasional 2015, (8) live in pendeta perwakilan dari Jerman Indonesia tahun 2015. Kegiatan ini merupakan sarana dalam memberikan wawasan kepada santri agar dapat memiliki perilaku/sikap sikap saling mengenal, antar etnik, agama, budaya, suku, negara yang beragam.

Para santri Pesantren Ngalah dapat berinteraksi secara langsung langsung dengan para agamawan dan tokoh non muslim, santri mampu beradaptasi menghadapi budaya yang berbeda jauh dengan dunia pesantren. ${ }^{6}$ Berdasarkan fenomena-fenomena yang diuraikan dalam konteks tersebut, maka tujuan penelitian ini menggali lebih mendalam tentang (1) Bagaimana Karakter Inklusif-Pluralis Santri di Pesantren Ngalah? (2) Bagaimana Strategi Pembentukan Karakter Inklusif-Pluralis Santri di Pesantren Ngalah?

\section{METODE}

Penelitian ini menggunakan pendekatan kualitatif bertujuan untuk mendeskripsikan, memahami, dan menginterpretasi fenomena-fenomena, peristiwa, aktivitas sosial yang terjadi di pesantren Ngalah Pasuruan. Jenis studi kasus (case study) dipilih dalam penelitian ini, karena penelitian dilakukan terhadap suatu kesatuan system dalam bentuk program, aktivitas,

5 Buku khutbah, Koleksi Khutbah Ala Pesantren Ngalah Cerminan Nilai Kedamaian. (Pasuruan: Pesantren Ngalah, 2011).,26.

${ }^{6}$ Abdul Ghofur, Wawancara, 09 Januari 2016 
peristiwa-peristiwa atau sekelompok ${ }^{7}$ individu yang terikat oleh tempat, waktu, atau ikatan tertentu yaitu tertang strategi pembentukan karakter inklusif-pluralis di Pesantren Ngalah Pasuruan. Kehadiran peneliti dalam penelitian ini bersifat mutlak, karena peneliti sebagai instrument kunci (human instrument).

Sumber data terdiri dari dua, yaitu manusia (human) dan bukan manusia. Sumber data manusia sebagai subjek atau informan kunci (key informant) yang berkaitan dengan strategi pembentukan karakter inklusifpluralis. Sedangkan sumber data bukan manusia berupa dokumen, catatancacatan yang relevan. Seperti peristiwa atau aktivitas berkaitan tentang : Karakter Inklusif-Pluralis Santri di Pesantren Ngalah, dan Strategi Pelaksanaan Pembentukan Karakter Inklusif-Pluralis Santri di Pesantren Ngalah. Penentuan informan Pertama, dengan teknik purposive sampling. Kedua, dengan teknik snowball sampling. Data dikumpulkan dengan tiga prosedur yaitu: 1) wawancara mendalam (indepth interview); terhadap informan kunci yang barkaitan dengan Nilai karakter InklusifPluralis dan strategi pembentukannya 2) observasi partisipan; terhadap aktivitas dan peristiwa yang ada di Pesantren Ngalah dalam pembentukan karakter inklusif-pluralis dan 3) studi dokumentasi (studi dokumen). Yaitu dokumen yang berkaitan dengan fokus penelitian.

Teknik analisis data menggunakan teknik analisis model interaktif dengan menempuh tiga langkah yang terjadi secara bersamaan menurut Miles dan Huberman yaitu: 1) reduksi data, yaitu menggolongkan data tentang nilai karakter inklusifpluralis dan strategi pembentukannya membuang data yang tidak ada kaitannya dengan focus penelitian; 2) penyajian data, yaitu: menemukan pola-pola hubungan yang bermakna tentang nilai karakter inklusif-pluralis, dan strategi pembentukan karakter inklusif-pluralis serta memberikan kesimpulan dari data yang telah disajikan berdasarkan pada focus penelitian; dan 3) penarikan kesimpulan/verifikasi.

Pengecekan keabsahan data menggunakan metode kredibilitas, sebagai salah satu langkahlangkah yang didasarkan pada empat kriteria pengecekan keabsahan data sebagaimana menurut Lincoln dan Guba bahwa pelaksanaan pengecekan keabsahan data didasarkan pada empat kriteria yaitu derajat kepercayaan, meliputi; (1) perpanjangan pengamatan, (2) triangulasi (a) triangulasi sumber, (b) triangulasi teknik, dan (c) triangulasi waktu.

\section{PEMBAHASAN}

${ }^{7}$ M. Djunaidi Ghony \& Fauzan Al Manshur.Metodologi Penelitian Kualitatif. (Jogjakarta : ArrRuz Media, 2014), 89 


\section{PENDIDIKAN MULTIKULTURAL}

\section{Karakter Inklusif-Pluralis Santri di Pesantren Ngalah}

Nilai karakter Inklusif-pluralis (terbuka menerima perbedaan) juga dikembangkan di pesantren Ngalah. Berdasarkan pada hasil temuna di lapangan, nilai karakter inklusif-pluralis telah diimplementasikan dan dikembangkan di Pesantren Ngalah hal ini tercermin pada saat penerimaan santri yang akan belajar di Pesantren Ngalah semua santri diterima dari latar belakang yang beragam, suku,bahasa, ras, status sosial. Selain itu, santri baru atau santri lama dalam penempatan kamar asrama tidak ada perbedaan, baik santri itu berasal dari desa maupun kota, anak pejabat ataupun anak petani semuanya menempati kamar dan mendapatkan fasilitas yang sama, karena yang membedakan hanyalah ketaqwaannya. ${ }^{8}$

Berdasarkan hasil wawancara di atas, bahwa Pesantren Ngalah telah mengimplementasikan nilai pluralis hal ini dibuktikan pada saat penerimaan santri baru tidak membeda-bedakan status social, suku, bahasa, dari masingmasing individu santri, semuanya diterima di Pesantren Ngalah dan dibimbing serta dididik, karena sama-sama mencari ilmu, yaitu sama-sama manusianya dan sama-sama mencari ilmu. Hal ini senada dengan Maarif menyatakan bahwa Inklusif adalah Sikap atau cara pandang terbuka yang dapat menerima perbedaan kelompok dan agama orang lain, membangun nilainilai kemanusiaan, melahirkan nilai baru yang modern, egaliter dan lebih mengedepankan sikap dialog dalam memecahkan permasalahan. ${ }^{9}$ Nilai Inklusif di Pesantren Ngalah merupakan sikap perwujudan dari pemahaman, keyakinan, dan pengalaman terhadap agama Islam.

Dalam konteks karakter Inklusif dalam perspektif agama, menurut Shihab terdapat tiga langkah yang dilakukan untuk menuju inkluvisme agama, Pertama; setiap kelompok agama harus memiliki kemauan, kesadaran, serta mau mendengarkan satu sama lain tanpa harus mengorbankan prinsip-prinsip ajaran agama yang dianutnya. Kedua, setiap penganut agama harus mampu melepaskan perasaan benci historis mereka dan bersama-sama melibatkan serta menganjurkan nilai-nilai dasar yang dilandaskan pada ajaran agama masing-masing Ketiga, para tokoh dan pemuka agama harus menentukan arah, strategi dan langkahlangkah agar para pengikutnya bisa menerapkan secara penuh kesadaran dalam mengerjakan ajaran berdasarkan keimanannya seraya menumbuhkan sikap toleransi beragama yang merupakan tujuan utama sebagai tujuan yang didukung dan dimajukan oleh Negara. ${ }^{10}$

\footnotetext{
${ }^{8}$ Kantor Pondok Pesantren Ngalah, Observasi, (Purwosari, 30 Mei 2017)

${ }^{9}$ Syamsul Maarif.Pesantren Inklusif: Berbasis

Kearifan Lokal. Cet. I (Yogyakarta: Kaukaba, 2015). 57.

${ }^{10}$ Alwi Shihab, Islam Inklusif :Menuju Sikap Terbuka Dalam Beragama,
} (Bandung :Mizan, 1997), 35-36. 
Hal ini diperkuat dengan dawuh KH. M. Sholeh B. pada saat pengajian rutin Senin malam Selasa, bahwa Pesantren Ngalah ini ibarat sepur (kereta Api) yang memiliki 6 gerbong, gerbong pertama berisi golongan tiyang seng sugih, pengusaha, pejabat, pakaiannya sae, sepatuan, gerbong kedua berisi golongane TNI, POLRI, gerbong ketiga berisi golongane dosen, guru, ustadz, gerbong ke empat berisi golongane karyawan pabrik, WTS, pencuri, gerbong kelima berisi golongane tukang cukur, tukang pande, gerbong ke enam berisi buruh kebun, buruh tani, buruh pabrik, penjual asongan, pengemis seng pakaiannya compang-camping, dan pengamen, serta ada penumpang yang naik di atas gerbong tidak mau membayar bahkan ketika ditanya karcisnya dia marah-marah, kabeh niku kulo antarkan ten tujuane enggeh niku stasiun kanthi selamat. ${ }^{11}$

Berdasarkan hasil observasi nilai inklusifpluralis ini diimplementasikan dan dikembangkan di Pesantren Ngalah tercermin pada sikap santri yang dapat menerima, menghargai, menghormati, serta dapat berinteraksi social dengan sesame santri yang memiliki perbedaan latar belakang suku, budaya, dan bahasa. Tamu yang datang ke pesantren Ngalah semuanya tanpa terkecuali diterima dan disambut dengan ramah, dan santun, baik tamu yang itu muslim, maupun dari Non muslim, baik itu pencuri maupun polisi, semuanya dijamu dengan ramah, santun dan baik.

Gus Dur menyatakan bahwa teologi Islam yang inklusif adalah rahmatan lil alamin (rahmat/kesejahteraan bagi seluruh alam) teologi tersebut merupakan pilar moderatisme Islam. Dalam konteks ini, ajaran Islam tidak diarahkan kepada eksklusifisme seperti mencurigai atau membenci agama lain, merendahkan memusuhi non muslim, serta menggunakan kekerasan sebagai wahana dakwah dalam menyiarkan kebenaran, bahkan Islam inklusif menyiarkan toleransi beragama dan juga kerja sama dengan non muslim. Perbedaan agama tidak menjadi suatu penghalang untuk dapat melakukan interaksi dan aksi sosial. Berdasarkan historisnya Islam menganjurkan untuk merangkul, berinteraksi dan bekerja sama dengan non-muslim dalam membangun masyarakat, maka secara subtansi ajaran Islam menekankan pada sikap harmonisasi dan mempromosikan wajah perdamaian bukan kekerasan bahkan terorisme. ${ }^{12}$

Senada dengan itu, menurut Shihab bahwa teologi inklusif dalam ajaran Islam menganut prinsip-prinsip moderat. Penegakan kebenaran harus dilakukan dengan jalan kebenaran pula, bukan dengan jalan kekerasan. Kemauan dan kesadaran untuk menghormati agama lain adalah perwujudan

${ }^{11}$ KH. M. Sholeh B. Dokumentasi Hasil Rekaman Pengajian Rutin Pada Pengajian Seninan Malam Selasa.

${ }^{12}$ Abdurrahman Wahid, Op.Cit, 44. 


\section{PENDIDIKAN MULTIKULTURAL}

dari sikap moderat. Sikap moderat seperti ini tidak berarti bahwa tidak konsisten terhadap ajaran agama, melainkan sebuah penghormatan akan seseorang. Karakter inklusif memiliki semangat mencari kebenaran dan mendialogkannya, tidak menggunakan kekerasan sebagai satu-satunya wahana dalam menegakkan kebenaran. Lebih bersikap terbuka ketimbang keras kepala taashub, baik dalam menerima kebenaran yang ada dalam agama nonIslam, maupun bersama-sama membangun masyarakat yang menjunjung tinggi nilai-nilai kemanusiaan. ${ }^{13}$

Nilai pluralis yang diimplementasikan dan dikembangkan di Pesantren Ngalah tercermin pada saat penerimaan santri yang akan belajar di Pesantren Ngalah semua santri diterima dari latar belakang yang beragam, suku,bahasa, ras, status sosial. Selain itu, santri baru atau santri lama dalam penempatan kamar asrama tidak ada perbedaan, baik santri itu berasal dari desa maupun kota, anak pejabat ataupun anak petani semuanya menempati kamar dan mendapatkan fasilitas yang sama, karena yang membedakan hanyalah ketaqwaannya. Dari sini dapat diketahui bahwa nilai pluralis di Pesantren Ngalah adalah mengakui, meyakini, dan menghargai situasi atau kondisi dari sebuah entitas yang bersifat plural (jamak) lebih dari satu baik latar belakang sosial, bahkan keyakinan sekalipun.

Pluralis dari segi etimologi, berasal dari kata pluralism berarti jama' atau lebih dari satu. Sedangkan dari segi terminology, sebagaimana menurut Naim adalah sesuatu yang tidak hanya sekedar keadaan atau fakta yang bersifat plural, jamak, atau banyak. ${ }^{14}$ Dalam bergaul dan bersosialisasi dengan dengan kelompok atau entitas yang memiliki agama yang berbeda, umat beragama diharapkan masih memiliki komitmen yang kokoh terhadap ajaran agama masing-masing. ${ }^{15}$

Sikap pluralis dimaksud disini bukan berarti mencampuradukkan agama (sinkretsime), hal ini sebagaimana menurut Shihab pengertian pluralisme ada tiga macam : pertama, pluralisme tidak semata menunjuk pada kenyataan tentang adanya kemajemukan. Namun pluralisme yang dimaksud disini adalah keterlibatan aktif terhadap kenyataan adanya keanekaragaman masyarakat tersebut. Kedua, pluralisme tidak sama dengan kosmopolitanisme. Dalam konteks ini kosmopolitanisme menunjuk pada suatu realitas di mana keragaman ras, budaya, dan bangsa dapat hidup berdampingan di satu lokasi. Maksudnya walaupun suatu ras, budaya dan

${ }^{13}$ Alwi Shihab, Islam Inklusif :Menuju Sikap Terbuka Dalam Beragama,

(Bandung :Mizan, 1997). 35-36.

14 Ngainun Naim dan Achmad Sauqi, Pendidikan Multikultural Konsep dan Aplikasi, (Jogjakarta: Ar-Ruzz Media, 2008), 75.

${ }^{15}$ Syamsul Ma'arif, Pendidikan Pluralisme di Indonesia, (Jogjakarta: Logung Pustaka, 2005), 17 
bangsa tersebut dapat hidup berdampingan, namun tidak ada interaksi sosial yang terjadi. Ketiga, konsep pluralisme berbeda dengan relativisme. Relativisme ini menganggap bahwa semua agama itu sama. Keempat, pluralisme agama bukanlah sinkretisme, yaitu menciptakan suatu agama baru dengan memadukan unsur tertentu atau sebagian komponen ajaran dari beberapa agama untuk dijadikan bagian integral dari agama tersebut. ${ }^{16}$ Nilai pluralism yang ada di pesantren Ngalah merupakan suatu faham yang mengakui, menghormati, dan menyakini adanya sebuah perbedaan dan adanya keaneka ragaman ras, suku, bahasa, dan Agama yang dapat hidup berdampingan di dalam suatu entitas.

\section{Strategi Pembentukan Karakter Inklusif-Pluralis Santri di Pesantren Ngalah}

Strategi pembelajaran merupakan suatu rencana, metode, dan perangkat kegiatan yang direncanakan untuk mencapai tujuan pembelajaran. Strategi pembelajaran sebagaimana menurut Gulo dapat dikelompokkan berdasarkan pada (1) komponen yang mendapat tekanan dalam pembelajaran, Strategi pembelajaran yang berdasarkan pada komponen yang mendapat tekanan dalam pembelajaran ada tiga macam yaitu; strategi yang berpusat pada guru (teacher centered), berpusat pada siswa (student centered), dan berpusat pada materi (matter centered). (2) kegiatan pengolahan pesan dan materi ada dua macam: strategi pembelajaran ekspositori dan heuristic (3) pemrosesan pesan dan materi ada dua macam strategi deduksi dan induksi. ${ }^{17}$

Berbeda dengan pendapat di atas, bahwa strategi dalam pembelajaran yang berorientasi pada penanaman nilai dan pendidikan keagamaan menurut Muhajir yang dikutip Muhaimin ada lima macam yaitu; (1) strategi indoktrinasi, (2) strategi bebas, (3) strategi keteladanan, (4) strategi klarifikasi, dan (5) strategi traninternalisasi. ${ }^{18}$ Strategi merupakan sebuah cara, atau metode yang digunakan atau diterapkan untuk mencapai suatu tujuan tertentu. Kaitannya dengan pembentukan karakter inklusifpluralis santri, strategi merupakan hal yang harus dilakukan setiap guru agar apa yang menjadi tujuan dapat terwujud dan tercapai dengan baik, karena tanpa strategi yang jelas, tujuan di dalam pembelajaran akan sulit dilakukan.

$41-42$

${ }^{16}$ Alwi Shihab, Islam Inklusif Menuju Sikap Terbuka, (Bandung: MIzan, 1997).

${ }^{17}$ W. Gulo, Strategi Belajar Mengajar, (Jakarta:PT Grasindo, 2002), 11-

12.

${ }^{18}$ Muhaimin, Paradigma pendidikan Islam: Upaya Mengefektifkan Pendidikan Agama Islam di Sekolah. (Bandung: PT Remaja Rosdakarya, 2002), 99. 


\section{PENDIDIKAN \\ MULTIKULTURAL}

Berdasarkan pada paparan data ditemukan strategi yang dilaksanakan Pesantren Ngalah dalam menanamkan nilai-nilai pendidikan multikultural adalah sebagai berikut;

\section{Keteladanan Multikultural Kiai}

Dalam pembentukan karakter inklusifpluralis di Pesantren Ngalah terdapat strategi-strategi yang diimplementasikan Kiai agar santri lebih mudah memahami dan dapat mengimplementasikan nilai-nilai yang ada di Pesantren Ngalah. Strategi yang terapkan oleh kiai berdasarkan hasil observasi adalah keteladanan (uswah) Kiai yang meliputi keteladanan yang mencakup aspek kognitif, psikomotorik dan afektif.

Strategi keteladanan kiai sebagai salah satu strategi yang dilakukan di dalam menanamkan nilainilai multikultural di Pesantren Ngalah, hal ini sesuai dengan pendapat Muhaminin bahwa strategi yang digunakan di dalam pendidikan keagamaan dan pendidikan nilai (sikap, jiwa, dan rasa) adalah keteladanan, hal ini karena ajaran agama atau nilai yang diberikan guru kepada peserta didik memiliki keterbatasan pengetahuan, pengalaman, serta kemampuan santri dalam perbendaharaan bahasa, atau kata-kata. ${ }^{19}$ Kaitannnya dengan keteladanan Kiai yang ada di pesantren Ngalah dalam pembentukan karakter inklusif-pluralis mengacu pada dimensi kognitif, afektif, dan psikomotorik, hal ini sesuai dengan karakteristik santri yang beragama di Pesantren Ngalah, maka penanaman nilai melalui keteladanan atau peragaan hidup secara riil lebih efektif dan mudah difahami dan dijadikan contoh oleh santri, karena santri belajar dengan cara melihat langsung, mendengarkan, dan meniru pola pikir, wawasan, perilaku, sikap yang kemudian santri menyesuaikan dan mengintegrasikan dirinya.

Senada dengan di atas, Ramayulis menyatakan bahwa keteladanan pendidik merupakan kunci utama keberhasilannya dalam mempersiapkan, mendidikan dan membentuk moral spiritual, dan sosial anak. Hal ini karena kiai merupakan figure sentral dan figure terbaik di Pesantren dalam pandangan santri yang akan dijadikan panutan dalam mengidentifikasikan diri di dalam segala aspek kehidupannya yang terpatri di dalam jiwa, perasaan, yang tercermin di dalam ucapan dan perbuatannya. ${ }^{19}$

Keteladanan yang diimplementasikan di Pesantren Ngalah berdasarkan hasil analisis, dapat di ketegorikan menjadi tiga macam, yaitu; Pertama, multikultural kognitif, yaitu keteladanan kiai berupa pemikiran, gagasan, prinsip, paradigma atau ide, mind set, pola pikir kiai tentang wawasan dan pemahaman terhadap nilai-nilai pendidikan multikultural, hal

${ }^{19}$ Ramayulis, Ilmu Pendidikan Islam, Cet. Ke V (Jakarta: Kalam Mulia, 2006), 174. 
ini dibuktikan dengan adanya selebaran-selebaran nasehat atau maklumat kiai yang diedarkan kepada para santri, tamu, dan jamaah pada saat pengajian Seninan, jamaah manaqib dan Dzikrul ghofilin.

KH. M. Sholeh B. sebagai role model (uswah) di pesantren Ngalah sikap dan prilakunya mencerminkan nilai-nilai multikultural yang dapat dilihat dan diikuti setiap waktu oleh santrinya. Selain melalui sikap atau perilaku kiai, dalam memberikan wawasan kepada santrinya melalui pemberian materi-materi atau selebaran teks-teks yang berisi nasehat atau maklumat tentang menyikapi pola pikir dalam menghadapi situasi dan kondisi politik di Indonesia yang diedarkan kepada seluruh santri atau dipajang di papan pengumuman atau bahkan di pasang di pigura pada setiap tempat-tempat yang mudah dilihat oleh santri.

Selain itu pengetahuan secara langsung yaitu menunjukkan langsung aktivitas yang dilakukan bersama non muslim. Hal ini dibuktikan dengan hasil wawancara dengan MS, bahwa langkah-langkah yang dilakukan agar santri memiliki wawasan yang sesuai dengan kiai Sholeh menurut saya (1) keteladanan Romo Yai. Biasanya kalau ada tamu non muslim yang datang ke Romo Kiai diajak masuk masjid dan duduk disamping Kiai pada saat pengajian Tafsir, sehingga semua santri dapat melihat secara langsung sikap Kiai terhadap Non Muslim. (2) pada saat pengajian tafsir Kiai Ngutus Santri untuk mencatat nasehat atau pesan Kiai pada tafsirnya. (3) mendiskusikan dawuh yai yang belum dapat difahami oleh santri di asrama yang diprogramkan oleh pengurus asrama. ${ }^{20}$

Berdasarkan hasil wawancara dengan MS di atas, langkah yang dilakukan adalah ketika ada tamu non muslim yang datang ke Pesantren Ngalah, sikap kiai adalah mengajak tamu non muslim tersebut untuk duduk disamping kiai pada saat pengajian tafsir sedang berlangsung, sehingga para santri dapat menyaksikan secara langsung sikap kiai terhadap tamu non Muslim. Ini menunjukkan bahwa dalam penerapan nilai-nilai toleransi, kemanusiaan di Pesantren Ngalah bukan hanya sebatas dalam tataran teori saja, namun sudah diterapkan dalam kehidupan sehari-hari.

Kedua, multikultural afektif, yaitu keteladanan kiai melalui gaya atau makna yang menunjukkan perasaan kiai tentang pernyataan yang bermuatan nilai-nilai pendidikan multikultural. Hal ini dibuktikan dengan adanya pesan atau nasehat kepada santri pada saat pengajian tafsir dan jamaah pada saat pengajian Seninan dengan melalui cerita-cerita atau kisahkisah kaum-kaum yang sukses atau tidak sukses atau cerita para ulama terdahulu dengan harapan santri memiliki antusias dan termotivasi dalam mengimplementasikan pendidikan multicultural. Hal ini diperkuat oleh

${ }^{20}$ Muhsinin, Wawancara. (Pasuruan, 23 Januari 2017) 
pendapat Ramayulis bahwa pendekatan yang dapat dilakukan dalam membentuk nilai karakter pada siswa adalah emosional, yaitu usaha untuk menggugah, dan membangunkan perasaan dan emosi siswa dalam meyakini ajaran Islam serta dapat merasakan sesuatu mana yang baik dan mana yang buruk. ${ }^{21}$ lebih lanjut, emosi adalah gejala jiwa yang ada di dalam diri seseorang, dan berhubungan dengan perasaan.

Ketiga, multikultural psikomotorik yaitu keteladanan kiai yang dicontohkan kepada santri melalui aktivitas, sikap, dan kegiatan secara langsung disaksikan oleh santri atau jamaah yang berkaitan dengan wawasan multikultural.

Karakter inklusif-pluralis yang diimplementasikan di Pesantren Ngalah sebagaimana tercermin kepada sikap Kiai, antara lain menjunjung tinggi harkat dan martabat manusia nilai-nilai kemanusiaan, menghormati adanya perbedaan, toleransi, kebersamaan, persaudaraan, demokrasi, perdamaian. Adanya nilai-nilai pendidikan multikultural yang diterapkan oleh Kiai selain karena kedalaman ilmu yang dimiliki juga terdorong karena kesufiannya, wawasan serta sikap tersebut sebagai bentuk perwujudan dari penerapan ajaran thoriqoh al-Naqshabandiyah, al-Mujaddadiyah alKholidiyah). ${ }^{22}$ Thoriqoh ini mengajarkan kepada penganutnya untuk berbuat baik kepada semua makhluk tanpa terkecuali apalagi sesama manusia baik kecil atau besar, laki-laki atau perempuan, tidak pandang golongan, etnik, budaya, agama, maupun antar negara. Hal ini diperkuat dengan kewajiban thoriqoh sebagai berikut;

\section{Kewajiban Thoriqoh}

Kewajibane thariqah ono nenem

Kewajiban ahli thoriqot itu ada enam

Siji dzikir marang Allah kanthi temen

Pertama, Berdzikir kepada Allah dengan bersungguh-sungguh

Kapindune iku nyegah hawa nafsu

\section{Kedua, mencegah hawa nafsu}

Telu tinggal bondo dunya ingkang palsu

Ketiga, meninggalkan dunia fana Kaping pate anut tuntunan agama

Keempat, menjalankan ajaran agama

Marang perintah lan cecegah kudu nerimo

Menjalankan perintah dan menjauhi/mencegah laranganNya

${ }^{21}$ Ramayulis, Ilmu Pendidikan Islam, Cet. Ke V ( Jakarta: Kalam Mulia, 2006), 171.

22 Abdul Ghofur, Kepala Pondok, Wawancara, Sengonagung, 10 Desember 2016. Lihat juga di dokumentasi Pondok Pesantren Ngalah, diambil 31 Juli 


\section{Kaping lima ambagusi kabeh kanca}

Kelima, berbuat baik kepada sesama manusia

Cilik gede, lanang wadon, enom tuwa

Baik kecil-besar, pria-wanita, muda-tua

Kaping nenem iku gawe kebagusan

Keenam, Berbuat kebajikan

Marang opo wae makhluke Pengeran

Kepada semua makhluk Tuhan tanpa terkecuali ${ }^{23}$

Hal ini juga selaras dengan hadits Nabi Muhammad SAW"khoirun annas anfa'uhum li annas" (manusia yang paling baik adalah manusia adalah manusia yang dapat memberikan kemanfaatan kepada manusia yang lain). Berdasarkan pada hadits itu, Kiai mengajarkan kepada para santri dan jama'ahnya agar menjunjung tinggi perdamaian, cinta, dan kasih sayang diantara sesama, menghargai perbedaan supaya mereka benar-benar menjadi manusia yang beradab.

\section{Mendiskusikan Dawuh Kiai dan Jawabul Masail}

Berdasarkan hasil observasi, salah satu strategi yang dilakukan Pesantren Ngalah dalam menanamkan nilai pendidikan multikultural pada santri adalah adanya forum "diskusi dawuh Kiai" forum ini terdiri dari pengurus asrama dan ketua kamar. Materi yang dibahas adalah maklumat atau pesan kiai yang disampaikan pada saat pengajian tafsir. Selain itu materi yang dibahas berasal dari kitab Jawabul Masail yang merupakan kumpulan hukum fiqih yang mencantumkan hokum yang boleh, dan hukum yang tidak boleh yang berkaitan dengan dimensi sosial dan ritual.

Pembahasan dalam diskusi ini bertujuan akar santri memiliki sikap yang luwas dan luwes dalam menghadapi permasalahan yang ada di masyarakat. Hal ini sesuai dengan pendapat Muhaimin bahwa strategi yang digunakan dalam penanaman nilai adalah moral reasoning. ${ }^{24}$ Yaitu penerapan diskusi yang dilakukan dengan adanya penyajian dilema hukum atau persoalan-persoalan yang bersifat kontradiktif-yang tercantum di dalam buku jawabul masail, atau dawuh Kiai-kemudian masalah tersebut didiskusikan dengan beberapa mengasilkan pemahaman yang utuh,

${ }^{23}$ Santri Mbah KH. Munawir Kertosono, Santri KH. Sholeh Bahruddin. Sabilus Salikin: Jalan Para Salik. (Pasuruan: Pondok Pesantren Ngalah, 2012,), 61-62 . Lihat juga di KH. Abdullah Munawir, Sabilul Hidayah (Pasuruan: Pondok Pesantren Ngalah, tt), 2. Lacak di Ahmad an-Naqsyabandi al-Kholidi. Jaamiul Ushul fil Auliya' at-Turuqus al Shufiyah. Cet. I (Bairut, al Antasyar al-Arobiy. 1997), 28-29. Teks ini dibaca pada setiap Senin setelah Isya di Masjid Aminah sebagai pujian ketika akan memulai pengajian rutinan Senin Malam Selasa yang diikuti oleh jamaah yang memiliki latar belakang yang berbeda.

${ }^{24}$ Muhaimin, Paradigma Pendidikan Islam: Upaya Mengefektifkan Pendidikan Agama Islam di Sekolah. (Bandung: PT. Remaja Rosdakarya, 2002), 100. 


\section{PENDIDIKAN MULTIKULTURAL}

implikasi dari diskusi ini santri dapat memahami terkait maklumat, dawuhdawuh Kiai, atau yang tercantum di dalam Jawabul Masail, sehingga dapat menyikapi permasalahan-permasalah yang dihadapi secara luwas dan luwes (moderat).

\section{Pembelajaran berdasarkan Pengalaman Langsung}

Berdasarkan hasil observasi, Pesantren Ngalah di dalam menanamkan nilai-nilai multikultural kepada santri adalah dengan strategi pengalaman langsung yaitu santri dilibatkan secara aktif pada (1) program internal Pesantren meliputi aktivitas rutinan harian, mingguan, bulanan atau tahunan yang diselenggarakan pesantren Ngalah. Seperti pengajian kitab kuning di asrama, baik dengan system sorogan ataupun bandongan. (2) program ekternal dengan masyarakata atau dengan non muslim. Hal ini dibuktikan dengan adanya keterlibatan santri pada acara atau even-even yang diselenggarakan oleh Universitas, Pesantren dengan Non Muslim. Seperti keterlibatan santri menjadi panitia pada acara Dies Natalis Universitas Yudharta Pasuruan ke 15, selain itu keterlibatan santri menjadi panitia seminar nasional kerukunan antar umat beragama ini sebagai wahana dalam pengenalan identitas, suku, bahasa, ras secara langsung agar dapat memahami dan berinteraksi langsung dengan individu-individu yang memiliki keragaman latar belakang.

Kegiatan ini merupakan strategi pengalaman langsung yang diterapkan kepada santri, agar apa yang dialami oleh santri dapat memberikan pemahaman terhadap diri santri peribadi dan masyarakat pesantren. Seperti (1) seminar lintas agama dengan pembicara KH. Abdurrahman Wakhid (Gus Dur) sebagai perwakilan dari agama islam pada tahun 2003, (2) Kolokium Alim Ulama Se-Indonesia dalam acara Peresmian Universitas Yudharta Pasuruan pada tahun 2004 yang di hadiri oleh semua tokoh lintas agama, (3) seminar nasional kerukunan antar umat beragama yang dihadiri oleh tokoh lintas agama serta mengundang dari vatikan ( Roma) pada tahun 2006, (4) Seminar Kebangsaan dan Gebyar Budaya Umat beragama pada tahun 2010 yang menjadi nara sumber adalah tokoh lintas agama dan menghadirkan Rev Jasper Slop (Belanda), (5) live in 100 pendeta tahun 2010 selama 3 hari tinggal di Pesantren hidup bersama santri kegiatan ini sebagai tindak lanjut forum komunikasi antar umat beragama, (6) menerima kunjungan pendeta perwakilan yang berasal dari berbagai negara, mulai dari Filiphina, Srilanka, Papua, Jerman dan Indonesia (Medan, Nias) tahun 2011, (7) dialog "agama dan budaya" tingkat internasional 2015, (8) live in pendeta perwakilan dari Jerman Indonesia tahun 2015.

Pengalaman langsung merupakan strategi yang diimplementasikan di Pesantren Ngalah dalam pembentukan karakter inklusif-pluralis santri di 
Pesantren Ngalah. Hal ini sesuai dengan pernyataan Muhaimin bahwa pendekatan yang efektif di dalam penanaman nilai adalah pendekatan pengalaman ${ }^{25}$, senada dengan itu Djamarah menyatakan bahwa pengalaman yang dilalui oleh pendidik adalah guru yang baik,...belajar dari pengalaman adalah lebih baik dari pada sekedar bicara dan tidak pernah berbuat sama sekali. $^{26}$

\section{Keterlibatan Santri Dalam Penyusunan Karya Ngalah}

Berdasarkan hasil observasi strategi yang dilakukan pesantren Ngalah dalam menanamkan nilai-nilai pendidikan multikultural adalah penyusunan buku ala Pesantren Ngalah merupakan sebuah cerminan pemikiran Kiai yang disusun oleh santri agar apa yang menjadi harapan Kiai dapat terdokumentasikan dan tertuang di dalam buku karya Ngalah. Ini sebagai upaya agar santri dapat memiliki pedoman bagaimana hidup bermasyarakat saling menghargai, saling menghormati, saling menghargai dan menerima perbedaan. Hal ini dibuktikan dengan terbitnya beberapa karya santri madrasah diniyah sebagai pedoman dalam hidup berbangsa dan bernegara, seperti (1) menerjemah dan mengkaji piagam madinah, sebagai bentuk pemahaman tingkah laku dan sikap yang dilakukan Nabi Muhammad terhadap masyarakat arab pada zamannya yang memiliki kebudayaan, adat, dan agama yang berbeda.

Melalui pemahaman ini bertujuan agar santri dapat mencontoh terhadap perilaku Nabi kepada non muslim, (2) mengkaji pancasila dan memberikan dasar ayat al-Qur'annya sebagai langkah dalam memberikan wawasan kepada santri bahwa pancasila tidak terlepas dari agama, karena nilai-nilai agama secara universal tercermin dalam Pancasila. (3) Penyusunan kitab Fiqih Galak Gampil jilid 1,2,3,4, dan 5 yang di dalamnya memuat beberapa alternatif solusi dari beberapa permasalahan dalam kehidupan sosial (hablum minannas) dan masalah ibadah (hablum minallah) dari perspektif mazhab empat, (4) menyusun kitab fiqih Jawabul Masail bermadzhab empat jilid I dan II (2012), yang dilengkapi ensiklopedi fiqih jawabul masail bermadzhab empat (2013). (5) menerbitkan khutbah dengan judul koleksi khutbah ala pesantren ngalah cerminan nilai kedamaian edisi I, II, dan III (2007-2011). ${ }^{27}$ Isi khutbah tersebut memuat tema yang mencerminkan nilai-nilai kedamaian, toleransi, tolong menolong, saling mengenal dan saling berdampingan dalam bermasyarakat. Misalnya

${ }^{25}$ Ramayulis, Ilmu Pendidikan Islam, Cet. Ke V ( Jakarta: Kalam Mulia, 2006), 170.

${ }^{26}$ Ramayulis, Ilmu Pendidikan Islam, Op.Cit. 170.

${ }^{27}$ Dokumentasi Pesantren Ngalah Pasuruan, diambil 09 Januari 2017 


\section{PENDIDIKAN MULTIKULTURAL}

indahnya keragaman, Islam agama damai, Rukun dan Damai dalam perbedaan. ${ }^{28}$

Sesuai dengan temuan di atas, strategi penyusunan buku karya Ngalah merupakan salah satu strategi yang dilakukan di Pesantren Ngalah, hal ini sesuai dengan penanaman nilai menurut Ramayulis yaitu pendekatan Rasional, Pendekatan Rasional menurutnya adalah suatu pendekatan dengan mempergunakan rasio (akal) dalam memahami dan menerima kebesaran dan kekuasaan Allah. ${ }^{29}$ Hal ini sejalan dengan apa yang telah dilakukan di Pesantren Ngalah dalam menanamkan nilai multikultural dengan menggunakan rasional (akal) yaitu strategi penyusunan Jawabul Masail yang mencantumkan beberapa hukum seperti boleh, makruh, dan haram yang bersumber dari dasar-dasar islam yaitu al-Quran, al-Hadits, ijma' dan qiyas. Hal ini bertujuan untuk memahami dan menerima persoalan-persoalan yang dihadapi santri pada dimensi social (hablum minannas) maupun ritual (hablum minallah), sehingga santri dapat menyikapi persoalan tersebut di masyarakat sesuai dengan landasan Islam.

\section{PENUTUP}

Nilai karakter inklusif-pluralism yang ada di pesantren Ngalah merupakan suatu karakter yang menerima, mengakui, menghormati, dan menyakini adanya sebuah perbedaan dan adanya keaneka ragaman ras, suku, bahasa, dan Agama yang dapat hidup berdampingan di dalam suatu entitas yang bersifat plural (jamak) lebih dari satu baik latar belakang sosial, bahkan keyakinan sekalipun.

Keteladanan Multikultural Kiai; Pertama, multikultural kognitif, yaitu keteladanan kiai berupa pemikiran, gagasan, prinsip, paradigma atau ide, mind set, pola pikir kiai tentang wawasan dan pemahaman terhadap nilai-nilai pendidikan multicultural. Kedua, multikultural afektif, yaitu keteladanan kiai melalui gaya atau makna yang menunjukkan perasaan kiai tentang pernyataan yang bermuatan nilai-nilai pendidikan multikultural. Ketiga, multikultural psikomotorik yaitu keteladanan kiai yang dicontohkan kepada santri melalui aktivitas, sikap, dan kegiatan secara langsung disaksikan oleh santri atau jamaah yang berkaitan dengan wawasan multikultural.

\footnotetext{
${ }^{28}$ Buku khutbah, Op.Cit, 27.

${ }^{29}$ Ramayulis, Ilmu Pendidikan Islam, Cet. Ke V (Jakarta: Kalam Mulia, 2006), 172
} 


\section{DAFTAR PUSTAKA}

\section{Buku}

Abdullah Munawir, Sabilul Hidayah ( Pasuruan : Pondok Pesantren Ngalah,

$\mathrm{tt})$

Abdurrahman Wahid. Islam Kosmopolitan: Nilai-Nilai Indonesia dan Transformasi Kebudayaan. Jakarta: The Wahid Institute. 2010.

Ahmad an-Naqsyabandi al-Kholidi. 1997, Jaamiul Ushul fil Auliya' at-

Turuqus al Shufiyah. Cet. I Bairut, al Antasyar al-Arobiy.

Alwi Shihab, 1997, Islam Inklusif : Menuju Sikap Terbuka Dalam Beragama, Bandung: Mizan.

Buku khutbah, 2011, Koleksi Khutbah Ala Pesantren Ngalah Cerminan Nilai Kedamaian, Pasuruan .

M. Djunaidi Ghony \& Fauzan Al Manshur. 2014, Metodologi Penelitian Kualitatif. Jogjakarta: ArrRuz Media.

Muhaimin, 2002, Paradigma Pendidikan Islam: Upaya Mengefektifkan Pendidikan Agama Islam di Sekolah. Bandung: PT Remaja Rosdakarya. Wacana Pengembangan Pendidikan Islam. (Yogyakarta: Pustaka Pelajar, 2004)

Ngainun Naim dan Achmad Sauqi, 2008, Pendidikan Multikultural Konsep dan Aplikasi, Jogjakarta: Ar-Ruzz Media.

Ramayulis. 2006, Ilmu Pendidikan Islam, Cet. Ke V. Jakarta: Kalam Mulia.

Santri Mbah KH. Munawir Kertosono, Santri KH. Sholeh Bahruddin. 2012,

Sabilus Salikin: Jalan Para Salik. Pasuruan: Pondok Pesantren

Ngalah.

Syamsul Maarif, 2005, Pendidikan Pluralisme di Indonesia, Jogjakarta: Logung Pustaka. 2015, Pesantren Inklusif. Berbasis Kearifan Lokal. Cet. I,

Yogyakarta, Kaukaba.

W Gulo,. 2002, Strategi Belajar Mengajar,

Jakarta:PT Grasindo.

Zakiyudin Baidhawy, 2005, Pendidikan Agama

Berwawasan

Multikultural. Jakarta: Erlangga.

\section{Jurnal}

Ahmad An-Nahidil Nunu,. Pesantren dan Dinamika Pesan Damai dalam Edukasi Jurnal Penelitian Agama dan Keagamaan, Vol. 4 No. 3, Puslitbang Pendidikan Agama dan Keagamaan: Badan Litbang dan Diklat Departeman Agama RI, 2006. 
Yusuf Hanafi. Model Pendidikan Pesantren Yang Toleran dan Inklusif Berbasis Culture of Peace Education Sebagai Upaya Mengikis Radikalisme Atas Nama Agama. Dalam Jurnal LP3. Universitas Negeri Malang. 2016.

\section{Internet}

Sholihuddin, Pesantren dan Budaya Damai,dalam http://www.gpansor.org/?p=13308, diakses pada tanggal 07 Januri 2017. 
STRATEGI PEMBENTUKAN KARAKTER INKLUSIF-PLURALIS MELALUI KETELADANAN MULTIKULTURAL KIAI DI PESANTREN NGALAH PASURUAN (Achmad Yusuf) 